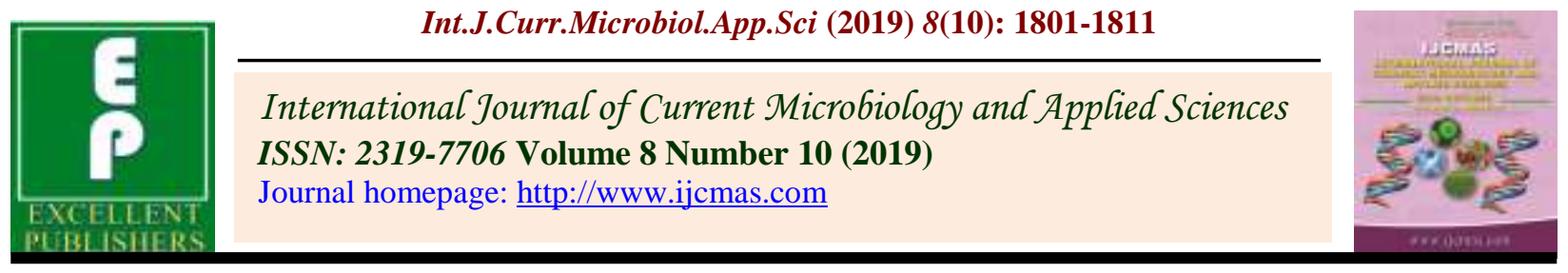

Original Research Article

https://doi.org/10.20546/ijcmas.2019.810.209

\title{
Multiple Gene Characterization of Rice Orange Leaf (ROL) Phytoplasma Infecting Rice
}

\author{
P. Valarmathi ${ }^{1 *}$ and D. Ladhalakshmi ${ }^{2}$ \\ ${ }^{1}$ Department of Plant Pathology, ICAR-Central Institute for Cotton Research (CICR), \\ Regional Station, Coimbatore-641 003, India \\ ${ }^{2}$ Department of Plant Pathology, ICAR-Indian Institute of Rice Research (IIRR), \\ Hyderabad-500 030, India \\ *Corresponding author
}

\section{A B S T R A C T}

\section{Keywords}

Rice Orange Leaf

(ROL)

phytoplasma, 16S-

23S rRNA Spacer,

16SrI- tuf gene,

secY gene

Article Info

Accepted:

15 September 2019

Available Online:

10 October 2019
Phytoplasmas are intracellular obligate prokaryotes that lack cell walls and have very small genomes (680-1,600 kb). Many fungal, bacterial and viral diseases have been characterized and resistant breeding programme is progressing very well. Recently, on the basis of the symptoms and on 16SrDNA sequence identity and phylogenetic relationships the association of ' $\mathrm{Ca}$. P. asteris' with Rice Orange Leaf phytoplasma disease in South India was confirmed. Rice orange leaf phytoplasma was characterized based on multiple gene systems. The 16S-23S rRNA Spacer region of rice phytoplasma was amplified by the primer pairs p1/p7 and p3/p7 at $\sim 320$ bp from all rice samples. The phytoplasma infecting rice samples were confirmed as group I by the group specific primer for $16 \mathrm{SrI}$ which amplified DNA fragment at $\sim 1.1 \mathrm{~kb}$ in all the samples. The tuf gene in phytoplasma ( $1000 \mathrm{bp})$ and phytoplasma in rice belonging to aster yellow (AY) group was confirmed by the primer specific for aster yellow tuf gene with amplification at $\sim 940 \mathrm{bp}$. The primer pair, AYsecYF1 and AYsecYR1 was used which amplified the secY gene at $\sim 1.4 \mathrm{~kb}$ in all the rice samples which confirmed the phytoplasma infecting rice belonged to aster yellow group. This is the first report to study multiple gene systems of Rice Orange Leaf (ROL) phytoplasma infecting Rice crop.

\section{Introduction}

Phytoplasmas are intracellular obligate prokaryotes that lack cell walls and have very small genomes (680-1,600 kb). Since the first report by Doi et al., (1967), phytoplasmas have been identified as pathogens in different plant genera and in some cases have caused severe epidemics in major crops (Bertaccini et al., 2014). Phytoplasmas cause complex syndromes with symptoms such as stunting, proliferating auxiliary shoots, forming sterile deformed flowers, virescence and phyllody in several hundred plant species (Lee et al., 
2000). Based on phylogenetic analysis of gene sequences (16S rRNA) phytoplasmas were recently assigned to a provisional genus, 'Candidatus (Ca.) Phytoplasma' within the class Mollicutes (Anonymous, 2004). The aster yellows (AY) phytoplasma group (16SrI) is the most dominant group comprises with more than 100 economically important diseases worldwide, representing the most diverse phytoplasma group (Lee et al., 2004; Bertaccini et al., 2014). The highly conserved 16S rRNA gene sequence has been used as the primary molecular tool for classification of phytoplasmas. A total of 19 distinct groups, termed 16S rRNA groups (16Sr groups), based on actual RFLP analysis of PCRamplified 16S rDNA sequences or 33 groups based on in silico RFLP analysis have been identified (Lee et al., 1998, 2000; Wei et al., 2007; Bertaccini et al., 2014). They are transmitted from plant to plant by grafting and other vegetative propagation techniques and by phloem-feeding insects, especially leafhoppers, planthoppers and psyllids (McCoy et al., 1989, Weintraub and Beanland, 2006; Olivier et al., 2012). Most phytoplasmas are transmitted from plant to plant by leafhoppers in a persistent manner.

The Poaceae family has the largest number of species associated with phytoplasma diseases worldwide and is also the plant family where the majority of phytoplasma vector species (Delphacidae) are known. Rice yellow dwarf (RYD) and Rice orange leaf (ROL) are the two phytoplasma diseases that have been reported to infect rice (Arocha and Jones, 2010). RYD, a serious problem for rice farmers and has only been detected todate in Asia (Nakashima et al., 1993). The infected rice crop turns pale yellow and gradually starts to decay and produce numerous tillers. ROL phytoplasma is caused by 'Candidatus Phytoplasma asteris' and was widely distributed in South and South-east Asia including Thailand, Malaysia, Indonesia,
China, Sri Lanka and the Philippines (Hibino et al., 1987). ROL phytoplasma is reported to be transmitted by the leafhopper Recilia dorsalis Motchulsky in the Philippines in persistent manner (Hibino et al., 1987), which also transmits rice dwarf virus and rice tungro virus (Ling, 1972). Based on the 16S rDNA sequence analysis phytoplasma associated with the ROL belonged to $16 \mathrm{Sr}$ I group and RYD belongs to the 16SrXI group (Jung et al., 2002).

Recently in India, on the basis of the symptoms, $16 \mathrm{Sr}$ DNA sequence identity and phylogenetic relationships, association of ' $\mathrm{Ca}$. Phytoplasma asteris' with ROL disease in South India was confirmed (Valarmathi et al., 2013). Hence an attempt was made to identify the associated phytoplasmas upto using multiple gene systems for the first time in India.

\section{Materials and Methods}

\section{Extraction of DNA from rice samples}

Modified CTAB method (Warokka et al., 2006) was used for the extraction of total DNA from leaf samples of rice for detecting phytoplasma. Infected sample $(0.4 \mathrm{~g})$ was initially ground in liquid nitrogen using a precooled mortar and pestle and then incubated for $10 \mathrm{~min}$ in $2 \mathrm{ml}$ of Phytoplasma Grinding Buffer, PGB in a centrifuge tube. Then add $1.25 \mathrm{ml}$ more of PGB. The homogenate was centrifuged for $5 \mathrm{~min}$ at 420 g. The supernatant of each sample was transferred into clean tubes and centrifuged for $25 \mathrm{~min}$ at $9677 \mathrm{~g}$. The pellet was dissolved in $1 \mathrm{ml} \mathrm{CTAB}$ buffer. After one-hour incubation at $65{ }^{\circ} \mathrm{C}$, the nucleic acids were purified by chloroform-isoamyl alcohol (24:1) extraction and an equal volume of ice cold isopropanol was added to the drawn aqueous phase and then incubated on ice for $1 \mathrm{~h}$. After centrifugation at $6720 \mathrm{~g}$ for $10 \mathrm{~min}$, the pellet 
was dissolved in $400 \mathrm{ml}$ of TE $(10 \mathrm{mM}$ Tris$\mathrm{HCl} \mathrm{pH} 8.0,1 \mathrm{mM}$ EDTA) to which $40 \mathrm{ml}$ of 3 $\mathrm{M}$ sodium acetate and $0.9 \mathrm{ml}$ of $95 \%$ ethanol were added. After incubation for $2 \mathrm{~h}$ at $-20{ }^{\circ} \mathrm{C}$, the mixture was centrifuged for $10 \mathrm{~min}$ at $6720 \mathrm{~g}$. Once the supernatant was eliminated, the tubes were washed with $80 \%$ ethanol, the pellet containing the DNA was dissolved in 35 $\mu 1$ of sterile water. The DNA was checked by $0.8 \%$ agarose gel electrophoresis.

\section{Amplification of 16S rRNA gene of phytoplasma by nested PCR}

The nested PCR approach was followed to detect the phytoplasma present in the disease infected rice samples. Six sets of primer pair as described were verified for the specificity in amplifying 16S rRNA gene of phytoplasma. All the PCR assays were performed in a thermal cycler (TECHNE TC 5000, Germany). One microlitre of DNA was used for first round amplification with primer pair $\mathrm{p} 1 / \mathrm{p} 7$ and $0.5 \mu \mathrm{l}$ of first round product was used as template in nested-PCR without dilution with phytoplasma specific primers $\mathrm{R} 16 \mathrm{~F} 2 \mathrm{n} / \mathrm{R} 16 \mathrm{R} 2$. Aliquots of $10 \mu \mathrm{l}$ PCR products were analyzed by horizontal gel electrophoresis (Bangalore Genei) on $1.5 \%$ agarose with ethidium bromide $(0.5 \mu \mathrm{g} / \mathrm{ml})$ using TAE (Tris buffer, EDTA, Glacial acetic acid and water) as the running buffer. The sample was mixed with $2 \mu \mathrm{l}$ of gel loading buffer $(0.25 \%$ Bromophenol blue $+40 \%$ Sucrose in $100 \mathrm{ml}$ of water) then loaded with gel slots. The gel was visualized with a UV transilluminator and photographed in the gel documentation system (Alpha Innotech Corporation, USA).

\section{Detection of phytoplasma based on multiple gene systems}

The PCR approach was followed to detect the phytoplasma present in the infected rice samples based on multiple gene systems. Four sets of primer pair as described in the Table 1 were verified for their specificity in detecting phytoplasma based on the group I of phytoplasma, aster yellow group, elongation factor tuf gene and secretion Y gene.

\section{Results and Discussion}

\section{Detection of phytoplasma based on multiple gene systems}

The detailed result of characterizing rice phytoplasma based on multiple gene systems were furnished in Table 2. The primer, $\mathrm{p} 4 / \mathrm{p} 7$ PCR products amplified $\sim 530 \mathrm{bp}$ in length which include the 16S-23S rRNA Spacer Region and part of 16S rRNA gene from all rice samples (Plate 1a). The 16S-23S rRNA Spacer Region of rice phytoplasma was amplified by the primer pairs, p1/p7 and p3/p7 at $320 \mathrm{bp}$ from all the rice samples (Plate $1 b$ ).

The phytoplasma infecting rice samples were confirmed as group I by the group specific primer for $16 \mathrm{Sr}$ I which amplified DNA fragment at $\sim 1.1 \mathrm{~kb}$ in all the samples (Plate 2a). The elongation factor ( $T u f$ gene), which is a well-conserved gene with a central role in translation for phytoplasma were analyzed by the group specific primer tuf revealed amplification at $\sim 1000 \mathrm{bp}$ from all the rice samples (Plate 2b). The phytoplasma in rice belonging to aster yellow (AY) group was confirmed by the primer specific for aster yellow tuf gene with amplification at $\sim 940 \mathrm{bp}$ (Plate 3a). The secY gene which encodes a protein involved in protein secretion used for differentiation of AY group phytoplasma were studied by the $\sec \mathrm{Y}$ primer results in amplification of DNA fragment at $\sim 1.4 \mathrm{~kb}$ in all the samples (Plate 3b).

Some additional tools for phylogenetic analyses and finer strain differentiation of phytoplasmas such as rp, secY, tuf, groEL genes and the 16S-23S rRNA intergenic 
spacer region sequences have been used as supplementary tools selecting those providing the most useful and reliable taxonomic information in combination with $16 \mathrm{~S}$ rDNA.

The phylogenetic relationships of sugarcane grassy shoot phytoplasma strains to each other and to closely related phytoplasmas infecting mainly gramineous plant worldwide, at both $16 \mathrm{~S}$ rRNA gene and 16S-23S rDNA spacer region sequence level were examined (Rao et al., 2007). Similarly the 16S-23S rRNA Spacer Region and part of $16 \mathrm{~S}$ rRNA gene was studied in the rice samples which amplify at $\sim 530 \mathrm{bp}$.

The phytoplasma 16S-23S rRNA intergenic spacer region contains a portion that codes for the highly conserved tRNAIle. However, the flanking sequences that extend from the tDNAIle to $16 \mathrm{~S}$ rDNA and to $23 \mathrm{~S}$ rDNA are variable among various phytoplasmas.

The ISR can serve as a useful tool for differentiation of phytoplasma groups and subgroups. Overall, the ISR is comparable to the $16 \mathrm{~S}$ rRNA gene sequence in its capacity for use in delineating distinct phytoplasma lineages (Smart et al., 1996). To increase the sensitivity of PCR, the primer pairs $\mathrm{p} 1 / \mathrm{p} 7$ and p3/p7 designed to amplify the $16 / 23 \mathrm{~S}$ spacer region approximately $320 \mathrm{bp}$ in length in the aster yellow group by Wang and Hiruki (2001). Similarly the 16S-23S rRNA Spacer Region was studied in the rice samples which amplify at $\sim 320$ bp by the use of primer pairs, $\mathrm{p} 1 / \mathrm{p} 7$ and $\mathrm{p} 3 / \mathrm{p} 7$.

A specific primer pair, designed by Lee et al., (1994) for the amplification of a ribosomal DNA fragment from strains belonging to the 16SrI group and named R16 (I) F1/R1, is presently used for the amplification from strains related to ' $\mathrm{Ca}$. Phytoplasma asteris'. A specific phytoplasma product of $\sim 1.1 \mathrm{~kb}$ was obtained after nested amplification using R16 (I) F1/R1 primer pairs in DNA samples collected from bulb scales and leaves of all diseased lilies and periwinkle plants infected by the phytoplasma belonging to aster yellow group (Kaminska and Dziekanowska, 2002).

A specific phytoplasma product of $\sim 1.1 \mathrm{~kb}$ was obtained after nested PCR amplification using R16 (I) F1/R1 primer pairs in DNA samples collected from garlic and onion infected by the phytoplasma belonging to aster yellow group (Khadhair et al., 2002).

With the references to the above study, similar results were obtained from the rice samples by the use of primer R16 (I) F1/R1 to amplify DNA fragment of $\sim 1.1 \mathrm{~kb}$ confirming the phytoplasma infecting rice belonged to aster yellow group.

The tuf gene, encoding the elongation factor $\mathrm{Tu}(\mathrm{EF}-\mathrm{Tu})$, is a well - conserved gene with a central role in translation (Schneider et al., 1997) and there is a single copy of this gene in the phytoplasma genome.

This gene has often been used in phylogenetic studies for other bacteria. The primers amplified products of the expected size ( 1000 bp) for 16SrI AY, 16SrIII green valley $\mathrm{X}$ and vaccinium witches'-broom and $16 \mathrm{SrXII}$ stolbur (STOL) groups but failed to amplify from 16SrII faba bean phyllody and 16SrX AP (Schneider et al., 1997). It has been subsequently found that these primers also fail to amplify from the 16SrIV coconut lethal yellowing (LY) and 16SrXXII coconut lethal decline phytoplasmas.

The main use of tuf gene primers has therefore been to establish subgroups within the $16 \mathrm{Sr}$ groups, particularly within the 16SrI AY group (Marcone et al., 2000) and the 16SrXII 'Ca. Phytoplasma australiense' group (Streten and Gibb, 2005). 
Table.1 Primer sequences and PCR conditions adapted for PCR to detect different genes of phytoplasma used in the study

\begin{tabular}{|c|c|c|c|c|}
\hline $\begin{array}{l}\text { Primer } \\
\text { pair }\end{array}$ & Designation & Primer Sequences & $\begin{array}{l}\text { Annealing } \\
\text { Condition }\end{array}$ & References \\
\hline $\begin{array}{c}\text { Group } \\
\text { specific } \\
\text { primer-I }\end{array}$ & $\begin{array}{l}\text { R } 16(\mathrm{I}) \mathrm{F} 1 \\
\text { \& R16(I)R1 }\end{array}$ & $\begin{array}{l}\text { 5'- TAAAAGACCTAGCAATAGG-3' } \\
\text { 5'- CAATCCGAACTGAGACTGT-3' }\end{array}$ & $\begin{array}{l}50^{\circ} \mathrm{C} \text { for } 2 \\
\min \end{array}$ & $\begin{array}{l}\text { Lee et al., } \\
1994\end{array}$ \\
\hline $\begin{array}{c}\text { Group } \\
\text { specific } \\
\text { primer }(t u f \\
\text { gene })^{\mathrm{a}}\end{array}$ & $\begin{array}{l}\text { f Tuf AY } \\
\text { r Tuf AY }\end{array}$ & $\begin{array}{l}\text { 5' -GCTAAAAGTAGAGCTTATGA- 3' } \\
\text { 5'- CGTTGTCACCTGGCATTACC- 3' }\end{array}$ & $\begin{array}{l}55^{\circ} \mathrm{C} \text { for } \\
30 \mathrm{sec}\end{array}$ & $\begin{array}{l}\text { Schneider } \\
\text { et al., } 1997\end{array}$ \\
\hline $\begin{array}{c}\text { AY } \\
\text { specific } \\
\text { primer (tuf } \\
\text { gene) })^{\mathbf{a}}\end{array}$ & $\begin{array}{l}\text { f Tuf } 1 \\
\text { r Tuf } 1\end{array}$ & $\begin{array}{c}\text { 5' -CACATTGACCACGGTAAAAC -3' } \\
\text { 5'-CCACCTTCACGAATAGAGAAC- } \\
\text { 3' }\end{array}$ & $\begin{array}{l}45^{\circ} \mathrm{C} \text { for } \\
30 \mathrm{sec}\end{array}$ & $\begin{array}{l}\text { Schneider } \\
\text { et al., } 1997\end{array}$ \\
\hline $\begin{array}{l}\text { secY gene } \\
\text { primer }^{a}\end{array}$ & $\begin{array}{l}\text { AYsecYF1 } \\
\qquad \& \\
\text { AYsecYR1 }\end{array}$ & $\begin{array}{c}\text { 5' }^{\prime} \\
\text { CAGCCATTTAGCAGTTGGTGG- } \\
3^{\prime} \\
\text { 5' }^{\prime} \\
\text { CAGAAGCTTGAGTGCCTTTACC- } \\
\mathbf{3}^{\prime}\end{array}$ & $\begin{array}{l}66^{\circ} \mathrm{C} \text { for } 1 \\
\min \end{array}$ & $\begin{array}{l}\text { Lee et al., } \\
\quad 2006\end{array}$ \\
\hline
\end{tabular}

${ }^{\mathrm{a}}$ The other PCR conditions are $95^{\circ} \mathrm{C}$ for $1 \mathrm{~min}$ followed by 35 cycles of $95^{\circ} \mathrm{C}$ for $30 \mathrm{sec}$, appropriate annealing condition and $72^{\circ} \mathrm{C}$ for $1 \mathrm{~min}$ with final extension of $72^{\circ} \mathrm{C}$ for $10 \mathrm{~min}$

Table.2 Characterization of Rice Orange Leaf (ROL) phytoplasma based on multiple gene based systems

\begin{tabular}{|c|c|c|c|c|c|c|}
\hline Samples & $\begin{array}{l}\text { 16S-23S rRNA } \\
\text { Spacer Region } \\
\text { and part of } 16 S \\
\text { rRNA gene }\end{array}$ & $\begin{array}{c}\text { Intergenic } \\
\text { spacer region } \\
\text { (16S- 23S } \\
\text { rRNA) }\end{array}$ & $\begin{array}{c}\text { Group } \\
\text { specific } \\
\text { primer-I }\end{array}$ & $\begin{array}{l}\text { Group } \\
\text { specific } \\
\text { primer } \\
\text { (tuf gene) }\end{array}$ & $\begin{array}{c}\text { AY- } \\
\text { specific } \\
\text { primer (tuf } \\
\text { gene) }\end{array}$ & $\begin{array}{l}\text { sec } Y \\
\text { gene }\end{array}$ \\
\hline $\begin{array}{c}\text { Coimbatore- } \\
\text { ADT } 43\end{array}$ & $\checkmark$ & $\checkmark$ & $\checkmark$ & $\checkmark$ & $\checkmark$ & $\checkmark$ \\
\hline $\begin{array}{c}\text { Coimbatore- } \\
\text { CO } 39\end{array}$ & $\checkmark$ & J & J & $\checkmark$ & J & J \\
\hline $\begin{array}{l}\text { Coimbatore- } \\
\text { White Ponni }\end{array}$ & $\checkmark$ & J & $\checkmark$ & $\checkmark$ & $\checkmark$ & $\checkmark$ \\
\hline $\begin{array}{c}\text { Erode- } \\
\text { BPT } 5204\end{array}$ & $\checkmark$ & J & $\checkmark$ & J & $\checkmark$ & $\checkmark$ \\
\hline $\begin{array}{l}\text { Negative } \\
\text { (healthy } \\
\text { sample) }\end{array}$ & $X$ & $X$ & $X$ & $\mathrm{X}$ & $\mathrm{X}$ & $X$ \\
\hline
\end{tabular}


Plate 1a.Detection of ROL by $\mathrm{p} 1 / \mathrm{p} 7$ and $\mathrm{p} 4 / \mathrm{p} 7$

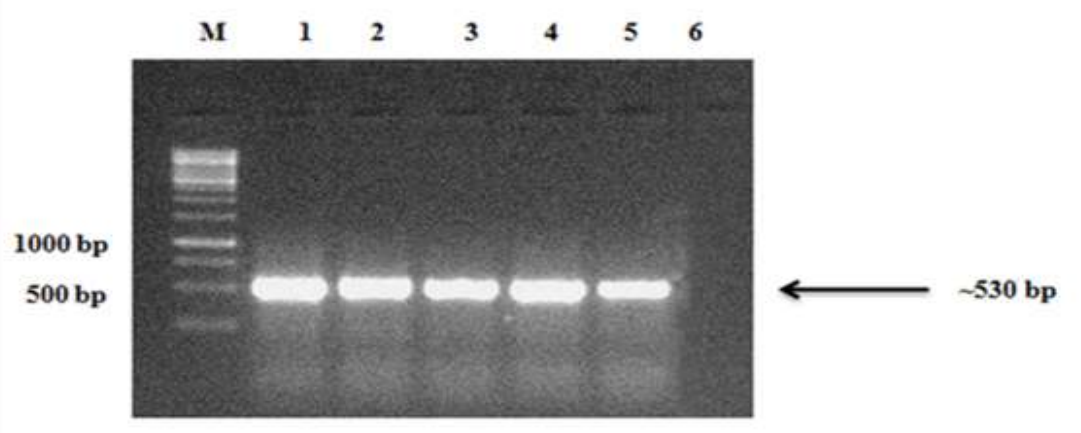

M- $1 \mathrm{~kb}$ DNA ladder

1- Rice (Erode- BPT 5204)

2- Rice (Coimbatore-White Ponni)

3- Rice (Coimbatore- $\mathrm{CO} 39$ )

4- Rice (Coimbatore- ADT 43)

5- Positive control (Infected brinjal)

6- Negative control (Healthy rice sample)

Plate 1b. Detection of ROL by $p 1 / p^{7}$ and $p 3 / p^{7}$

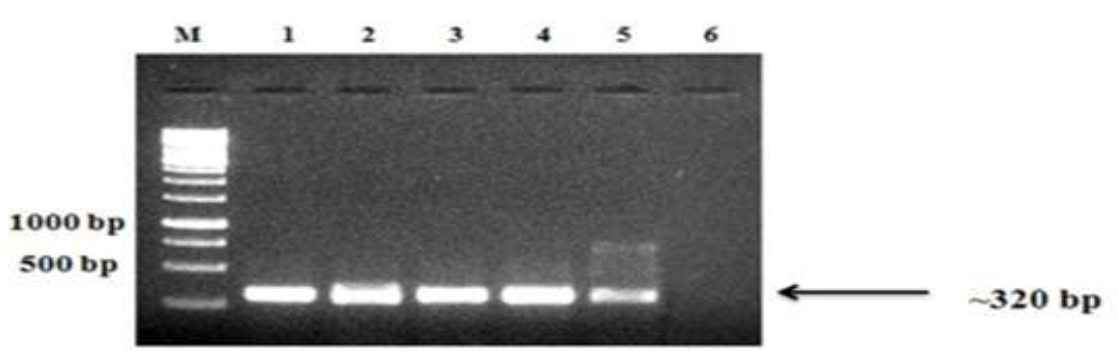

M- $1 \mathrm{~kb}$ DNA ladder

1- Rice (Erode- BPT 5204)

2- Rice (Coimbatore-White Ponni)

3- Rice (Coimbatore- CO 39)

4- Rice (Coimbatore- ADT 43)

5- Positive control (Infected brinjal)

6- Negative control (Healthy rice sample) 
Plate 2a.Detection of ROL by group specific primers for $16 \mathrm{SrI}$

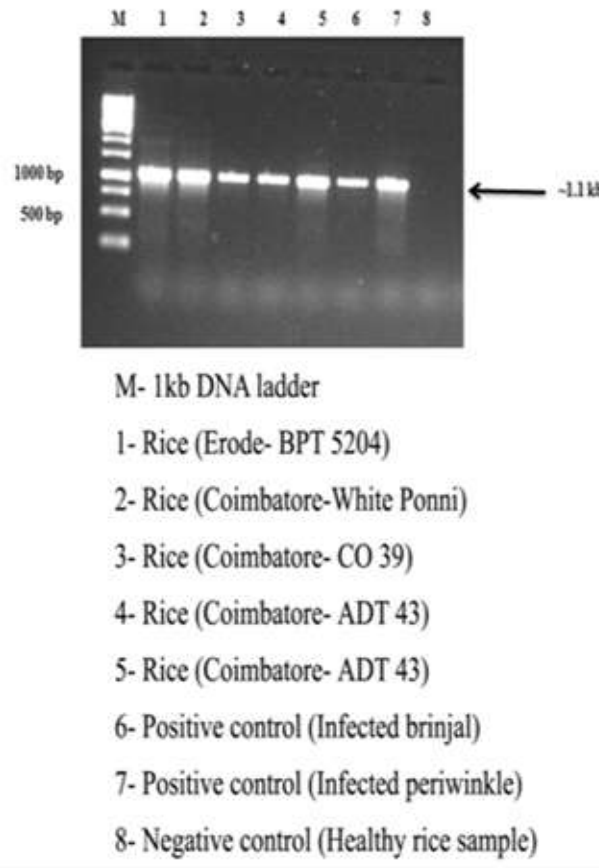

Plate 2b.Detection of ROL by group specific primers for tuf gene

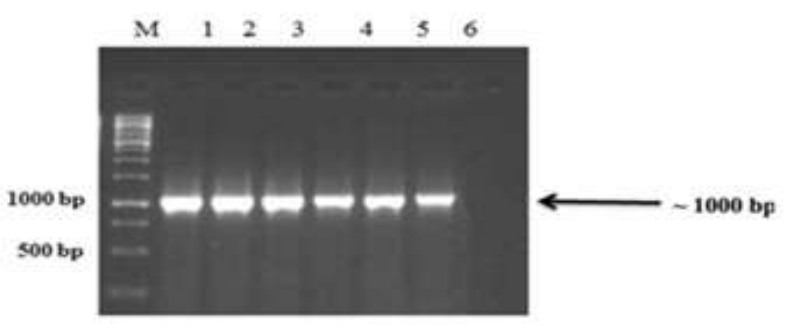

M- $1 \mathrm{~kb}$ DNA ladder

1- Rice (Erode- BPT 5204)

2- Rice (Coimbatore-White Ponni)

3- Rice (Coimbatore- CO 39)

4- Rice (Coimbatore- ADT 43)

5- Positive control (Infected brinjal)

6- Positive control (Infected periwinkle)

7- Negative control (Healthy rice sample) 
Plate 3a.Detection of ROL by Aster yellow group for tufgene

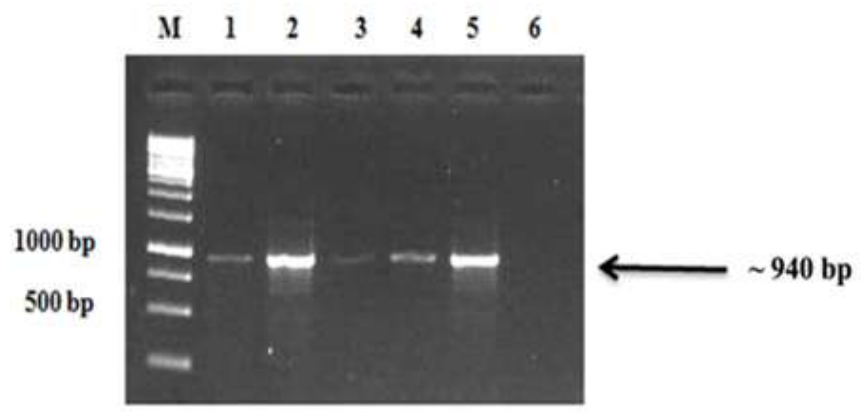

M- 1 kb DNA ladder

1- Rice (Erode- BPT 5204)

2- Rice (Coimbatore-White Ponni)

3- Rice (Coimbatore- CO 39)

4- Rice (Coimbatore- ADT 43)

5- Positive control (Infected brinjal)

6- Negative control (Healthy rice sample)

\section{Plate 3b.Detection of ROL by Aster yellow group sec gene}

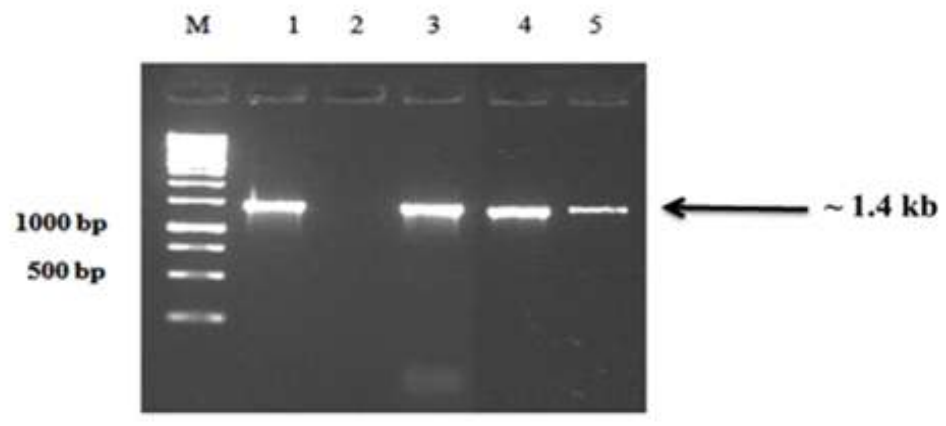

M- 1 kb DNA ladder

1- Rice (Erode- BPT 5204)

2- Negative control (Healthy rice sample)

3- Rice (Coimbatore-White Ponni)

4- Rice (Coimbatore- CO 39)

5- Rice (Coimbatore- ADT 43) 
In a study on the AY group, the AY-specific primers fTufAy $\left(5^{\prime}\right.$ GCT AAA AGT AGA GCT TAT GA 3') and rTufAy (5' CGT TGT CAC CTG GCA TTA CC 3') (Schneider et al., 1997), which amplify 940 bp product, were used on 70 phytoplasma isolates in conjunction with the $16 \mathrm{~S}$ rRNA gene primers (Marcone et al., 2000). The tuf gene in phytoplasma ( $1000 \mathrm{bp}$ ) and tuf gene of AY group ( 940 bp) has been confirmed in the rice samples by our study. These results were in agreement by the findings of Schneider et al., (1997) and Marcone et al., (2000).

The secY gene, which encodes a protein involved in the protein secretion mechanism from bacteria and has also been used for differentiation of the AY group phytoplasmas (Lee et al., 2006). Primers were designed based on the published AY and OY sequences to amplify a $1.4 \mathrm{~kb}$ near-full-length $\sec Y$ gene for AY group phytoplasmas. In our study, we used the primer pair, AYsecYF1 and AYsecYR1 to amplify the $\sec Y$ gene at $\sim 1.4$ $\mathrm{kb}$ in all the rice samples which confirms the phytoplasma infecting rice belonged to aster yellow group.

\section{References}

Anonymous, IRPCM Phytoplasma/ Spiroplasma Working Team Phytoplasma Taxonomy Group 2004. 'Candidatus Phytoplasma', a taxon for the wall-less, non-helical prokaryotes that colonize plant phloem and insects. International Journal of Systematic and Evolutionary Microbiology, 54: 1243-1255.

Arocha, Y. and Jones, P. 2010. Plant diseases of the Gramineae. In: Weintraub PGand Jones P (Ed.). PhytoplasmasGenomes, plant hosts and vectors. pp. 170-186.

Bertaccini, A., Duduk, B., Paltrinieri, S. and Contaldo, N. 2014. Phytoplasmas and
Phytoplasma Diseases: A Severe Threat to Agriculture. American Journal of Plant Sciences,5:17631788.

Doi, M., Tetranaka, M., Yora, K. and Asuyama, H. 1967. Mycoplasma or PLT-group like organism found in the phloem elements of plants infected with mulberry dwarf, potato witches' broom, aster yellow, or paolownia witches' broom. Annals of the Phytopathological Society of Japan, 33: 259-266.

Hibino, H., Jonson, G.B. and Sta Cruz, F.C. 1987. Association of mycoplasma-like organisms with rice orange leaf in the Philippines. Plant Disease, 71: 792794.

Jung, H.Y., Sawayanagi, T., Kakizawa, S., Nishigawa, H., Wei, W., Oshima, K., Miyata, S., Ugaki, M., Hibi, T. and Namba, S. 2002. 'Candidatus Phytoplasma castaneae', a novel phytoplasma taxon associated with chestnut witches' broom disease. International Journal of Systematic and Evolutionary Microbiology, 52: 15431549

Kaminska, M. and Dziekanowska, D. 2002. Molecular Evidence for the Presence of Aster Yellows-Related Phytoplasmas in Lilies with Leaf Scorch and Flower Virescence. Journal of Phytopathology, 150: 9093.

Khadhair, A. H., Evans, I. R. and Choban, B. 2002. Identification of aster yellows phytoplasma in garlic and green onion by PCR-based methods. Microbiological Research, 157: 161167.

Lee, I. M., Gundersen, D. E., Hammond, R. W. and Davis, R. E. 1994. Use of mycoplasma-like organism (MLO) group-specific oligonucleotide primers for nested-PCR assays to detect mixed- 
MLO infections in a single host plant. Phytopathology, 559-566.

Lee, I. M., Zhao, Y. and Bottner, K. D. 2006. $\mathrm{Sec} Y$ gene sequence analysis for finer differentiation of diverse strains in the aster yellows phytoplasma group. Molecular Cell Probes, 87-91.

Lee, I.M., Davis, R.E. and Gundersen, D.E. 2000. Phytoplasma, phytopathogenic mollicutes. Annual Review of Microbiology, 54: 221-255.

Lee, I.M., Gundersen, D.E., Davis, R.E. and Bartoszyk, I.M. 1998. Revised classification scheme of phytoplasmas based on RFLP analyses of 16SrRNA and ribosomal protein gene sequences. International Journal of Systematic Bacteriology, 48: 1153-1169

Lee, I.M., Gundersen, D.E., Davis, R.E., Bottner, K.D., Marcone, C. and Seemuller, E. 2004. 'Candidatus Phytoplasma asteris', a novel phytoplasma taxon associated with aster yellows and related diseases. International Journal of Systematic and Evolutionary Microbiology, 54: 1037-1048.

Ling, K.C. 1972. Rice Virus Disease. International Rice Research Institute, Los Bahos, Philippines, 142p.

Marcone, C., Lee, I. M., Davis, R. E., Ragozzino, A. and Seemuller, E. 2000. Classification of aster yellows-group phytoplasmas based on combined analyses of rRNA and tuf gene sequences. International Journal of Systematic and Evolutionary Microbiology, 50: 1703-1713

McCoy, R.E., Coudwell, A., Chang, C.J., Chen, C.J. and Chikowsik, L.N. 1989. Plant diseases associated with Mycoplasma like organisms. In: Whitcom, R.F and Tulley, T.G (Ed.). the mycoplasmas volume $\mathrm{V}$. spiroplasmas, a choleplasmas and mycoplasmas of plants and arthropod. pp. 545-640.

Nakashima, K., Kato, S., Iwanami, S. and Murata, N. 1993. DNA probes reveal relatedness of rice yellow dwarf mycoplasma like organisms (MLOs) and distinguish them from other MLOs. Applied and Environmental Microbiology, 59: 1206-1212.

Olivier, C.Y., Vincent, C., Saguez, J., Galka, B., Weintraub, P.G. and Maixner, M. 2012. Leafhoppers and planthoppers: their bionomics, pathogen transmission and management in vineyards. In: Bostanian N.J, Vincent C, Isaacs R. (Eds.), Arthropod Management in Vineyards: Pests, Approaches, and Future Directions. Springer, Dordrecht, The Netherlands, pp. 253-270

Rao, G. P., Srivastava, S., Singh, M. and Marcone, C. 2007. Phylogenetic relationships of sugarcane grassy shoot phytoplasma with closely related agents. Bulletin of Insectology, 60: 347-348.

Schneider, B., Gibb, K. S. and Seemuller, E. 1997. Sequence and RFLP analysis of the elongation factor $\mathrm{Tu}$ gene used in differentiation and classification of phytoplasmas. Microbiology, 143: 3381-3389.

Smart, C. D., Schneider, B., Blomquist, C. L., Guerra, L. J. and Harrison, N. A. 1996. Phytoplasma-specific PCR primers based on sequences of 16S-23S rRNA spacer region. Applied and Environmental Microbiology, 62: 2988-2993.

Streten, C. and Gibb, K. S. 2005. Genetic variation in Candidatus Phytoplasma australiense. Plant Pathology, 54: 814.

Valarmathi, P., Rabindran, R., Velazhahan, R., Suresh, S. and Robin, S. 2013. First report of Rice orange leaf disease phytoplasma (16SrI) in rice (Oryza sativa) in India. Australasian Plant 
Disease Notes, 8: 41-43.

Wang, K. and Hiruki, C. 2001. Use of heteroduplex mobility assay or identification and differentiation of phytoplasmas in the aster yellows group and the clover proliferation group. Phytopathology, 91: 546-552.

Warokka, J.S., Jones, P. and Dickinson, M.J. 2006. Detection of phytoplasmas associated with Kalimantan wilt disease of coconut by the polymerase chain reaction. Journal Littri
Puslitbang Perkebunan, 12(4): 154160.

Wei, W., Davis, R.E., Lee, I.M. and Zhao, Y. 2007. Computer-simulated RFLP analysis of $16 \mathrm{~S}$ rRNA genes, identification of ten new phytoplasma groups. International Journal of Systematic and Evolutionary Microbiology, 57: 1855-1867.

Weintraub, P.G. and Beanland, L. 2006. Insect vectors of phytoplasmas. Annual Review of Entomology, 51: 91-111.

\section{How to cite this article:}

Valarmathi, P. and Ladhalakshmi, D. 2019. Multiple Gene Characterization of Rice Orange Leaf (ROL) Phytoplasma Infecting Rice. Int.J.Curr.Microbiol.App.Sci. 8(10): 1801-1811. doi: https://doi.org/10.20546/ijcmas.2019.810.209 